\title{
Kırım Türklerinin Edebî Dil Gelenekleri: Kırım Hanı Bora Gazi Giray'ın Şiir ve Mektupları Üzerine YRD. DOÇ. DR. OLEG RUSTEMOV*
}

Öz

Kırım yarımadası ve kuzeyindeki, tarihte Deşt-i Kıpçak adıyla bilinen araziler, farklı dönemlerde çok sayıda ve farklı Türk kavimlerinin göç dalgalarını kabul etmişti. Buraya gelen bütün Türk halkları, kavim ve boylar, tarihte, özellikle dil tarihinde, kendi izlerini bırakmışlar. Dillerin karışıp ve çaprazlanması, dünya dillerinin oluşumunda olağan bir süreçtir. Kırım Tatar dili, birçok Türk lehçesinden ve başka komşu dillerden etkilenmiştir. Makalede Altın Ordu resmi dilinin, Osmanlıcanın ve Kuman veya Kıpçak denilen Kırım'daki yerel halkın dilinin son derece aktif şekilde etkileşime girdiği bir dönemde, Kırım Tatar edebi dilinin oluşum sorunsalını ele alıyor. Çalışmada kullanılan örnek malzemede Kuman dili, modern Kırım Tatar dilinin temelini oluşturmakla beraber, Altın Ordu'nun 'Türki'si ve özellikle Osmanlıcanın belirgin izleri görünmektedir. Dil materyali olarak Kırım Hanı Bora Gazi Giray'ın yarlığı (mektubu) alınmıştır. Yarlık ayrıca da çağdaş Türkçe 'ye çevrilmiştir.

Anahtar sözcükler: Dillerin karışıklığı, yarlık, Deşt-i Kıpçak, Türki, Codex Cumanicus, Kumanlar.

\section{Abstract \\ TRADITIONS OF LITERARY LANGUAGE OF THE CRIMEAN TURKS: ON POEMS AND LETTERS OF BORA GAZİ GİRAY}

The Crimean peninsula and the lands known as "Desht-i Kipchak" has accepted the many waves of immigration of different Turkic tribes in different periods. All the Turkic peoples, folks and tribes who came here have left their mark in history, especially in the history of language. Mixing and crossing languages is a normal process in the formation of world languages. The Crimean Tatar language has been influenced by many Turkish dialects and other neighboring languages. Article deals with the formation problematique of Crimean Tatar literary language in a period when the official language of the Golden Horde has a highly active interaction with Ottoman Turkish and the dialects of local people in Crimea (called as Kuman or Kipchak). In the sample used in the study, Kuman language appears to be the basis of modern Crimean Tatar language and it has also certain traces from

\footnotetext{
* Ardahan Üniversitesi İnsani Bilimler ve Edebiyat Fakültesi, olegrustemov@ardahan.edu.tr
} 
the Turkish of Golden Horde and especially Ottoman Turkish. The letter (yarlyk) of the Crimean Khan Bora Gazi Giray was taken as a sample of language. The text was also translated into contemporary Turkish.

Keywords: Mixing of languages, yarlyk, “Desht-i Kipchak”, Turkic, Codex Cumanicus, Coman.

\section{GİRIŞ}

Irım yarımadasına ve kuzeyindeki geniş bozkırlar Hun, Hazar, Bulgar, Avar,
Oğuz (Guz), Peçenekler, Selçuk, Kuman, Tatar gibi Türk kavim ve
halklarının uğrak yeri olmuş. Göçler sonucu buraya gelen bu kavimler buraları otlak olarak kullanmış ve yurt edinmişlerdir. Hatta bu bölge tarihte önce Mafazat al'Guzza (مفازة الغز) - ‘Oğuz bozkırı' ismiyle (bkz. Bartold V. V. (2002), S. 550), 12. yüzyıldan itibaren Deşt-i Kıpçak - Kıpçak Bozkırı olarak anılmıştır. Bu Türk boylarının konuştuğu lehçeler, Türk dil ailesinin farklı kollarına ait olan lehçelerdi ve bu boylar Kırım'ın tarihi gidişatını değiştirirken dilini de belirlemişlerdir.

Yarımada'ya Türk boylarının karmaşık göç tarihleri nedeniyle Kırım Tatarlarının XIIIXIV yy.'da yazılmış en eski dil yadigârı olan 'Codex Cumanicus'un dili bile karışık bir karakter taşır. Yadigârın dil çeşitliliği sadece morfoloji seviyesinde değil, leksikoloji açısından da görünür. Sözlükte farklı Türk ağızlarıyla alakalı çeşitli eş anlamlı kelimeler rasgelmektedir: alın - maňlay; kendi - öz; sövinç (sevinç) - quvanç; bilemek - qayramaq; yüzmek yaldamaq; benzemek - oqşamaq; beslemek - asramaq ve diğerleri (bkz. Komanisches wörterbuch. 1942). Lehçelerin morfolojik çeşitliliği ise yine farklı dil kaynaklarından gelen fiil çekimlerinin karışmasıdır. Meselâ, hem Oğuz hem de eski Kıpçak lehçelerinde duyulan geçmiş zamanı ifade eden -mış, ve yine Kıpçak ve Karluk lehçelerine ait olan duyulan geçmiş zaman hem de geniş zaman anlamı taşıyan -gan eki veya -ınca / -ince anlamına gelen Kıpçak ve Karluk lehçelerine has olan -ğanda / -gende ve eski Oğuz lehçesinin (Harezm ağzı) fiile gelecek zaman anlamı katan -daçı ekinin yan yana kullanılması (Argunşah-Galip. 2015. S. 124-126) bu rengârenk dil kaleydoskopunun parlak bir delilidir.

Çok-bileşenli dil durumlarının bir diğer örneği, başka bir yadigâr olan 1232 senesinde şair Ali tarafından yazılan 'Kıssa-i Yusuf' adlı nazımda bulunabilir. Eserin nerede yazıldığ belli değildir. Bu yüzden birçok Türkolog eserin yazıldığı yer için farklı hipotezler ortaya atmıştır (Borovkov. 1963. Brockelmann. 1916. Nacip. 1975). Bunlar arasında Volga' daki Saray şehrinde ya da Azerbaycan ve Orta Asya'daki edebi merkez olan Harezm'de yazıldığı iddiaları da vardır. Bu farklı görüşlerin temel sebebi, eserlerin Cengiz Han ve onun evlatlarının fütuhatları sonucunda oluşan kütlevî göçlerin dönemi ile çağdaş olmasıdır. Lâkin Prof. Ertaylan'dan ve kendi tespitlerimizden hareketle eserin dilinin Kırım'daki Oğuz- 
Kıpçak lehçesinin yapısı ile birçok noktada aynı olduğunu, bu yüzden Kıssa'nın Kırım’da yazıldığını söyleyebiliriz (Ertaylan. 1960. S. 11). Eski Kırım Türkçesine özgü ayrıntılar olan ortaçların -iban / ıban /-uban, -üben: sevünüben - severken; kirüben - girerken ${ }^{1}$ veya daha önce işaret ettiğimiz Codex Cumanicus'ta tespit olunmuş olan daçı / -taçı ekleri bu duruma delil gösterilebilir.

Kırım Tatar Lehçesi bugüne kadar kendine has tabiî gelişimini Oğuz-Kıpçak ağzı temelinde devam ettirebilirdi fakat XIII. yüzyılda başka kültür merkezleri gibi Deşt-i Kıpçak ve Kırım yarımadası da Moğol-Tatar akınlarına maruz kaldı. Tatarların Kırım istilası sonucunda bölgenin kuzey bozkır topraklarına Orta ve Doğu Asya kökenli kalabalık Türk ve Türkleştirilmiş Moğol boyları yerleşmiş ve yanlarında zamanla Batı-Kıpçak (Kuman) ağzıyla birleşecek olan ayrı bir Türk lehçesi getirdiler (Rustemov-Stepanov. 2016). Birleşme sürecinde Kıpçak lehçesi baskın çıkmış, öz Tatar lehçesi ise Kırım lehçesine birçok sübstratum izler birakmıştır.

Batuhan döneminde Kırım, Altın Ordu tertibatına (1233-1234) eklendi (Vernadskiy. 1997. S. 303). Bu zamandan beri Kırım'da resmi dil Altın Ordu Türkçesi (Türki) olarak görülmeye başlar. XIII-XIV yüzyıllarındaki Uygur lehçesi bu Türki için temel teşkil etmiştir: 'Söz geçen dönemde Moğolistan'da konuşulan ve resmi dil Moğolca idi. Bununla beraber Moğollarla aynı bölgelerde yaşayan Türklerin XIII-XIV yüzyıllar boyunca Uygurlarla temaslarının devam ettiği bellidir' (Grigoryev. 1978. S. 81). Uygur edebi lehçesi temelinde kurulan Altın Ordu resmi dili, XVII yüzyılın sonuna kadar Kırım Hanlığın kâtipleri arasında mektup ve yarlık/fermanların yazılmasında aktif olarak kullanıldı (Zaytsev. 2009). Böylece eski Kırım Türkçesinin gelişimi, yazılı dilde Kırım Hanlığı devrindeki mahkeme evrakları özelliği gösteren - XVII-XVIII yy. kazasker sicillerine aksetmiştir (Kırım kadıları sicillerin kopyaları / KKSK). Elbette, bu lehçede diğer Türk lehçelerinin, özellikle Osmanlı, bıraktığı tesirin izleri gayet çoktur.

XIII. asırda ortaya çıkan Türki, kullanıldığı zamanda diğer Türk lehçelerinden farklılık göstermeye başlamıştı (Nacip-Blagova. 1997. S. 126). Türki'nin farklı çeşitleri arasında, Kıpçak ve Oğuz ağızlarının büyük etkileri altında maruz kalan Kırım Türki'si ayırt ediliyordu. Bu etkiler ilk önce Kırım hanlarının mektup ve yarlıklarında görülmektedir. Elbette ilk çağlarda zamanla kuvvetlenen diğer lehçelerin tesirleri olmadığından Kırım Türki'si Volga (Altın Ordu) ve Orta Asya (Çağatay lehçesi) ile ortak özellikler gösteriyordu. Uygur edebi dilinden geliştirilmiş olduğundan bu Türki'nin bütün varyasyonları, Türk Dili Ailesinin Karluk-Çiğil-Uygur dalına ait hatta derlediği bölgelerin ağılarının gramer, fonoloji

\footnotetext{
${ }^{1}$ Kırım Tatar dilinde -ıban eki kullanılması için bkz. Samoyloviç. 1916. s. 64.
} 
ve leksikolojik özelikleri hakkında detaylı bilgiler veren Kaşgarlı Mahmut'un tespitleri 1şığında Karahanlıların resmi dili olan Hakaniye Türkçesidir.

\section{INNCELEME}

Kırım'ın meşhur hanı, şairi ve kahramanı Bora Gazi Giray'ın (1554-1607) Zigmut olarak adlandırılan Polonyalı kralı Sigizmund'a gönderilen yarlığı Türkisi'nin bir numunesi sıfatıyla hizmet edebilir (yarlık şu kaynaktan alındı: Velyaminov-Zernov. 1864. S. 9, 11-12.).

$\mathrm{Hu}$

Bi'l-kuvvet'ül-ehadiye-u ve'l-mûcizat'ül-Muhammediye Uluğ Ordu Uluğ Hanı Gazi Giray sözüm.

Allah ve Huday İzim ve İzzet ve Uğan Tengri Taalâ Hazretlerining ve Vahdaniyeti ve Azamat-i birlâ başlansun.

Oň qolnıng ve Sol qolnıng Uluğ ulusnıng Tümen bilgân ming, yüz, on bilgân oğlanlarınga ve bekleringe ve mirzalarınga ve Rus ve Prus knyazlarınga ve Aqbaşlı ve Qara toňlarınga, mesçanlırınga ve barça uluğ keňeş panlarınga, içki ve tışqılarınga ve köplük qara ilge barça tuzunca bilgânlâringâ basa Min ki, sansuz ve köplük Deşt-i Qıpçaqnıng Uluğ Padişahı Gazi Giray Han. Min Haq Subhaneh-u ve Taalâning Ulûvv İnayetleri Şan-1 Şerifimüzgâ mukarin ve muavin bolub Uluğ atalarımıznıng orunlarınga Taht-1 Haqanığa cülus müesser ve nasib boldı. İrse işbu Yarlı̆̆-1 Şerif-i Haqanımız birlâ beyan aşikâre q1larmız. Kim o eldin Uluğ Atamız uçmaqlıq Haci Giray Han ve önge Havagin'ül-izam ve Selatin'ül-kiram Rahmatulla aleyhim ecmain zamanlarında vilâyet İlâh memleket-i Qıralları olan Qazimir qural ve Zigmut Qiral ve Ahust qural ve sair qırallar çağlarında biri birisi birlâ dost muhabbet ve barış ve yarış bolub, iki curt arasında öksüz oğul ve tul hatun ve yarlı yayrınca başlarınga Altun Tac urub yürür bolsalar ve İslamçı tacir ve bazirgân varub kelür bolsalar, zarar ve ziyan körmey, emin barub aman kelür irdiler. Ama Ahust qiral fevt olduqta İlâh memeleketige qiral bolur oğul qalmay. İlâh memleketi on iki yıl quralsız bolub, memleket içinde olan hırsuz ve haramileri İlâh memlektning voyvodaları ve panları ve kermen bekleri tergemey ve zabt q1lmay. Zahire azuq verüb kemi verüb Özü suyuna kelüb, tatarıng tuvarcısıng alub ve tuvar ve yılqısıng sürüb song Macar qıralları uruğundıng İştefan qıral İlâh memleketige qiral bolub Özü suyunda olan kristiyanning hirsuz harami qazaqlarınğa rüayet itkân içün Özü suyunda harami ve hırsuz qazaqlar köplük bolub Özü suyundıng inüb devletlüğ ve saadetlük Padişah Hünkâr Hazretlerning Özü suyu boyunda olan Cankermen ve Aqkermen ve Bender kermening arasında olan qoycu ve tuvarcı ve bazirgân fakirlerigâ zarar ve ziyan körgizgânleri üçün Rahmetlik Babamız Devlet Giray Han ve Ağacalarımız Hanlar ve Özümüz ve Sultanlar ve Beşbaş tatar qazaqları İlâh memleketini her qış çapub iki curt bir birigâ düşman olurğa Özü Suyu içinde olan Harami hırsuz kristiyan qazaqları sebep olunmışlardır. Halâ İlâh memleketi qıralı bolğan Asoşqa qiral oğlu qarındaşımız Zigmut qıral Devlet Eşigimizgâ Uluğ elçisi Bronevskiyanı bölek hazinesi birlâ yiberüb burunğı barış ve yarış ve dost ve muhabbet yosunca iki curtumuz barış ve yarış bolub bazirgân emin varub ve aman kelüb kim kimsenedin zarar ve ziyan olmasın dediler. İrse yibergen Bölek hazinesiň hoş görüb alub qabul qılındı. Qarındaşımız Zigmut birlâ dost ve muhabbet ve barış ve yarışımıznı dahi şul şart üzerine qılamız ki, Özü suyu içinde olan harami ve hırsuz kristian qazaqları barcasın sürüb, Özü suyundan çıqarub tergep zabt itqâylâr. Ve ta ki yibere turğan bölek hazinesin her yıl yibergeyler ve defterimüz üzre 
kişilârimiznüng tiyişlerin bölek hazinesi ile bilgâ yibergeyler. Ve ta ki Qağılğa (qalğay) sultan olan qarındaşımız Fetih Girey sultanğa dahi altmış postaf çekmen bölek hazinesi ile bilgâ yibergeyler. Ve on iki kişigâ dahi tiyiş yibergeyler. Bu uslûb üzere bölek hazinesin verüb ve tiyişlerin bilgâ yiberür bolsalar ve Özü suyu içindin kristian qazaqların bir qoymay barcasıň çıqarur bolsalar barış ve yarış ve dost ve mühabbet bolub eğer, min özüm Ğazı Giray han bolay ve Uluğ Kiçik Qağılğa sultan başlı̆̆ barça sultanlar bolğaylar ve bekler ve mirzalar bolsun Tatar çerümiz birla çaparğa ve yaqub yıqarğa ve zarar ve ziyan qılarğa bir kimsene barmasın. Eğer sin qarındaşımız Ziğmut bu ahd ve şart üzerine turar bolsalar, vallahi ve billâh ve Tallahi dostuňuzğa dost ve düşmanıňığa düşman bolurmız. Ve ta ki beş baş qazaqlar barub il astındıng salanız çapub esir keltürür bolsalar Min qarındaşıňız Ġazi Giray han keltürgân esirlerni qayta alub yiberürmiz. Ve beş baş qazaqlarnıng ta ki haqlarındın kelürmiz. Özü suyu içinde turğan kristian qazaqlarıňıznı çıqarmaz bolsaňız Tatar tuvarcısığa ve tuvar qarağa zarar ve ziyan qılar bolsalar, Siz qarındaşımız Zigmut bilmiş bolsuň kim dostluq ve mühabbet ve barış ve yarış olmay. İki curt emin aman bolmaslar. Ve ta ki Siz Zigmut qarındaşımız Özü Suyu içinden ktistian qazaqlarıňıznı çıqarır bolsaňız Özü suyu boyunda bolğan qara rayyet il kişileriňiz kelüb, Çorqa tuzumızdıng aqçaları birlâ eminimüzding tuz satun alub ketsün. Sin Zigmut qarındaşımıznıng memleketige ve bizim memleketimizge bazirgânlar qorqmay ve usanmay emin varub aman kilgeyler.

Halâ uluğ elçiňiz Bronevskiyning közünce bu ant ve şart ve ahd idub bu ahd-name yarlığ-1 Şerif-i haqanımuzğa altun nişanlığ mührini basub Özümizning Ulug elçimüz olan İçki bekmiz olub vezirimüz olan Qasımnı bu ant ve şart ve ahdımıznı Siz qarındaşımız Zigmut bildirir içün yiberdik. Ve ta ki Siz Zigmut qarındaşımız Moskov düşmanıňığa atlaňğanıňızda Min Gazi Giray han qarındaşıňızdın yardım üçün Tatar çerüğin tilâr bolsaňız harclıq flori yibergeysiz ki, çerümizgâ verüb düşmanıňı üstüne cibergeymiz. Ve ta ki biz Gazi Giray han qarındaşıňızdıng varan Uluğ elçimüzi iki aydıng artuq tutqar qılmay bölek hazinesi ve tiyişler birlâ qayta tezoq biz qarındaşıňız̆̆a yibergeysiz. Ve Siz Zigmut qıral qarındaşımızdıng bizgâ kilgen Uluğ elçiňizni ta ki iki aydın artuq tutqar qılmay, sin Zigmut qıral qarındaşımızğa tezok ciberirmiz. İmdi sin Zigmut qıral qarındaşımız bilmiş bolsunlar kim Özü suyunı içinding qazaqlarıňıznı çıqarmay ve tergemey zabt q1lmaz bolursaňız biz qandaşıňıznıng tuvarcılarına ve tuvar qarağa zarar qılub ve Padişah Hünkâr Hazretlerning kermenlerine ve rüayasığa zarar ve ziyan qilar bolsalar dostluq ve muhabbetlik ve yarış ve barış bolmay. İki curtnın rüayası ve berayası zahmet körüb devletlüg Padişah Hünkâr Hazretlerinding dahi uyat bolursiz. Bu ahd ve şart ve ant üzerine turulmaq kerekdir deyü, ahd-name yarlı̆̆-1 Şerif-i Hakani bitildi. Fi Şehr-i Cümadi-ül- evvel. Min Şuhuri sene Elf.

Bi makam-i Almasaray, Dar-ül-Hakani. Han Ğazi Giray bin Han Devlet Giray.

Mektubun metni, bir parçası da Kırım'da bulunan zamanla ayrı uluslara ve devletlere ayrılan Cengiz Han İmparatorluğu'ndaki bütün Türk uluslarının dil yapılarından parçalar yansıtıyor. Yukarıda belirtildiği gibi, bu parçaların, Altın Ordu Türki'sinin diğer yerel Türk ağızlarıyla karıştırılması sonucu olduğu söylenebilir.

Yeni Uygur dilinin temelinde kurulan metinde görülen Altınordu Türkisi (aynı zamanda Çağatayca da diyebiliriz) dil özellikleri şunlardır: kelime hazinesi açısıdan; ong sağ (taraf), barça - hepsi, uyat - utanç, köp - çok, tiyiş (tiyişli) - gerek olunan, değerli (burada: 
vergilerin bir çeşidi) (Toparl. 2007. S. 278.); burungi - önceki, orun - yer, biti- - yazkelimeleri; fiillerin gruplarında tur- fiilinin yardımcı fiil işlevi: yibere turğan (gönderen, sürekli gönderen). Bu kelime ve formeller mektubun dilini öncelik eski Uygur ve daha sonra Karahanlılar devletinde kullanılan edebi dili temeli olan Orta Asya ve Çağatay lehçeleri ile yakınlaştırıyor. Bu unsurların sırasında da nazal (sonorant) diftong ile bitişen ayrılma hâli eki - -ding: eminimüzding (eminimizden), içinding (içinden). Yönelme hali eki - -ge / ğa (Oğuzca'nın -al-e yerine): bir birige düşman olurğa (bir birine düşman olmasına); tışqılarınga ve köplük qara ilge (dışkılarına ve çok sayıda kara halka). Anlamına göre isimden isim veya sıfat türeten -li / -lı eki yerine -lig / -lıq ekleri kullanılması: nişanlı yerine nişanlı̆̆, uçmaklı (rahmetli, cennette bulunan) yerine uçmaqlıq; devletlüğ (devletli) ve saadetlük (saadetli) Padişah.

Sentaks özellikleri açısından ise; 'tekrarlanan anlamları ifade eden' (Gaciyeva. 1986. S. 174) ta ki / taqı bağlacıyla ara-sıra başlayan ve onun yardımıyla oluşturulan birleşik sıralı cümleleri kayıt edebiliriz. Yarlık ve han mektuplarındaki bu tip cümlelerde anlaşmanın şartları, vergilerin çeşitleri ve hediyeleri veya yapacak gereken işler birer birer sayıldığ ${ }_{1}$ için çok uzun sözcük yapıları türetilebilir. Bu bağlaç anlamına göre çağdaş Türkçenin da / de, hem de; bazı da ise daha bağlaçları veya bundan başka, hatta ondan sonra gibi zarflar ile karşılaştırabilir. Yarlıkta geçen ta ki bağlacı Codex Cumanicus'taki dağı yani dahi bağlacı anlamina gelmektedir (Komanisches wörterbuch.1942. S. 81).

Fiillerinde kullanılan gelecek zamanin olumsuz kip eki olan -may de kendisine dikkati celp ediyor; krş. çağdaş Özbekçe: bermaydı (vermeyecek) bo'lmaydı (olmayacak). Ama yarlıktaki cümlelerin anlamına göre orada geniş zaman olumsuz eki, yani -maz / -mez, olması gerekiyor, meselâ: zarar ve ziyan qılar bolsalar dostluq ve muhabbetlik ve yarış ve barış bolmay (zarar ve ziyan getirirse dostluk ve muhabbetlik ve yarış ve barış olmaz). Zaten bu şekildeki fiiller de vardır, meselâ, çıkarmaz bolsanız... Ondan sonra gelecek zamanı oluşturan ek -gay / gey kullanıldığı takdirde, gelecek zaman olumsuzluğu ifade eden eki yine de sadece -may değil, -magay / -megey beklenirdi: bolmagay, kelmegey gibi. İhtimalin böyle kısaltması Kıpçak tesiri altında oluşmuştu. Öz metinde gördügüumüz gibi bu ek birkaç işlevi gerçekleştirir. Meselâ, bunun gibi: ... elçimüzi iki aydıng artuq tutqar qulmay bölek hazinesi ve tiyişler birlâ qayta tezoq biz qarındaşıňız̆̆a yibergeysiz (elçimizi iki aydan fazla tutmadan bölek ${ }^{2}$ hazinesi ve tiyişler ${ }^{3}$ ile bize, karındaşınıza geri çabuk gönderin) cümlede -may eki -madan / -meden ekiyle oluşturulan ortacı ifade ediyor.

Metinde görülen Kıpçak dil özellikleri ise şunlardır: Batı Kıpçak, yani Kırım’a has olan Oğuz-Kıpçak veya Kuman lehçesinin ögelerine ait olan kelime ve ekleri örnek için getirdiğimiz yarlıkta kene de açık-aydın görünmektedir. Meselâ Kuman kökenli yiber-

\footnotetext{
${ }^{2}$ Bölek - 1. Borçlar için ödenecek ve buna uygun surette bölünmüş mal. 2. Hediyeler, armağanlar.

${ }^{3}$ Tiyiş (tiyişler) - lüzumlu, ihtiyaç çekilen ve talep edilen şeyler. Burada: vergilerin bir çeşididir.
} 
(gönder-) fiili iki kökenden ibaret olup: biri ta Codex Cumanicus'ta tespit edilen ry- (yollamak, göndermek) ve yardımcı fiili rolü oynayan ber- (vermek) kelimesi zamanla birleştirilerek bir

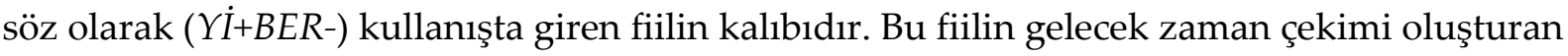
-gay / -gey eki: yibergeyler (gönderecekler yani) - Türki dili daha sonra ise Çağatay lehçesinde olmakla beraber kene de Codex Cumanicus'ta fiil çekimi bölümünde gösteriliyor (ArgunşahGalip 2015: 483, 104).

Mektubundaki yiber- / ciber- kelimesinin başlarında $y$ - ve $c$ - ünsüzlerin sıralaması veya yurt kelimenin curt şeklinde kullanılması da Tatarlar arasında Kıpçak lehçesi etkisinin oldukça büyümesine delalet ediyor: 'Oğuzlarla Kıpçaklar baş tarafında ' $ى$ '(i-1) bulunan isim

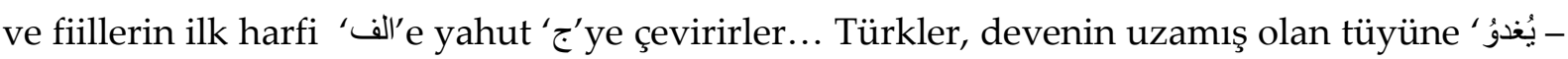
yuğdu’ derler, Oğuzlar ve Kıpçaklar ' جُجدو - cuğdu' derler' (Kaşgari. 1992. Cilt 1, S. 31).

Metinde görülen Ŏguzca özellikleri şunlardır: Osmanlıca ve belki de öz Kırımın Oğuz ağızlarının etkisini Karluk asıllı lehçelerine uyumlu olan sözlerin başındaki boğuk harfler yerine tonlu konsonların kullanılması gösteriyor. Meselâ mektupta ortaç körüp yerine görüb (كوروب) (görüp) olarak yazıyor. Bununla beraber başka satırda aynı kökten (kör- / gör-) oluşturulan ettirgen fiilli yaptıran -guz- / -giz- / -gez- eki (zarar ve ziyan körgezgenleri (كوركازكانلارى) / zarar ve ziyan gösterenleri) ise Codex Cumanicus' ta tespit edildiği dolasıyla Kıpçak lehçesinde de mevcuttur.

Metinde sik olarak var- ve bar- (gitmek) veya ver- ve ber- (vermek); bol- / ol- (olmak) karşıtları, Kıpçak tipindeki fiillerin duyulan geçmiş hem geniş zamanı belirten -ğan / -qan / gen / -ken (turğan) eki yanında Oğuzca sıfat-fiillerin -an / -en eki (olan, varan); Kıpçak ve Karluk kökenli 'deb', 'teb' zamir-fiili yerine Güney Türk şekli ‘deyü' rasgelmektedir. Bütün bu dil olayları Kırım hanlarının Diplomatik Müessesinde Osmanlıcanın gayet büyük ve sabit bir etkisi olduğuna delil oluşturuyor.

XVI yüzyıl yarlığı metnin örneğinde gösterilen dil olayları tarif edilmiş topraklarda eskiden çeşit Türk halkların birer birer hep yeni dalgaların akınları sayesinde; yani bir kavim yerine diğer boy geldiğinde öncekileri bazen tamamen yerinden kovar, bazen ise ayn bir bölgede beraberlikte yaşamayı devam ettiği dolasıyla ortaya çıkmıştır. Aslında metin hayatın göçebe tarzı sebebi olan edebi dillerin çatışmasını vasıflandırıyor. Sonuç olarak, heterojen yani çok-bileşenli, meselâ Codex Cumanicus'un da temeli olan ve onun yazıldığı zamandan beri sabit Oğuz-Kıpçak etkileri izlenebilecek Kırım Tatar lehçesi gibi dil yapıları kurulmuştur. Mektuptaki metinden görüldüğü gibi Kırım Hanlığ1 zamanında Altın Ordu Türki'sinin unsurları her ne kadar çok sübstratum seviyesinde olduysa yine de yerel Kırım lehçesi rekabetçilerin mücadelesinde galip gelmiştir.

Metindeki Slav dillerinden gelen özellikler ise: yine de Batı Kıpçak - Kuman lehçesi hazinesine ait olan yarlıkta geçen 'köy' anlamındaki 'sala' (Rusça: 'selo') sözü İslav alıntısıdır. 
Bu kelime ancak Kırım Türkçesinde kullanılmaktadır. Tarihi evraklardan hariç o Kırımın yer adlarında rasgeliyor: Fotisala, Büyüksala, Yaňısala (Yenisala). Diğer Türk lehçelerinde böyle kelime yoktur.

Metnin diğer bir sentaks özelliği, Arap kökenli [ve] bağlacı ile devrik cümlelerin başlamasıdır: "Ve Siz Zigmut kral qarındaşmızdın̆ bizgâ kilgen Uluğ elçiňizni ta ki iki aydın artuq tutqar qılmay..." - Ve (hem) Sizden, Sigmund kral, karındaşımızdan bize gelen Ulu elçinizi de iki aydan fazla tutmadan... Aşağıda yarlığın tarihi ve dilsel önemlisi var olduğu dolayı onun çevirisi takdim ederiz:

$\mathrm{Hu}$

Bir Olanın Kuvveti ve Hz. Muhammed'in mucizesiyle Ulu Ordu Ulu Hanı Gazi Giray sözüm.

Allah ve Huda İzin ve İzzet ve her şeye Gücü yeten Tanrı Teâla Hazretlerinin ve Vahdaniyet-i ve Azamat-i ile başlansın.

Sağ kolun ve sol kolun ulu ulusun tümenine komuta edenlere, binbaşılarına yüzbaşılarına, onbaşılarına; beglerine; mirzalarına; Rus ${ }^{4}$ ve Prusya kinezlerine; akbaşlıklı ve kara kürk giysili soylularına; meşanlarına6; tüm Büyük Meclisin ${ }^{7}$ ağalarına, merkezdekilere ve taşradakilere; kara buduna; tüm bunların tamamına hükümdarlık eden ben ki sonsuz, sınırsız Deşt-i Kıpçak'ın Ulu Padişahı Gazi Giray Han.

Bana Hak Sübhanallahu Teâlâ'nın yüce lütfuyla ve şerefli şanımıza yakın ve yardımcı olması sayesinde ulu atalarımızın makamı olan Taht-1 Hakani'ye oturmak kolaylıkla nasip oldu. Böylece işbu hakanımızın şerefli yarlığı ile açıkça beyan ederiz ki, o ilden ${ }^{8}$ ulu Atamız cennetlik Hacı Giray Han ve önceki büyük hanlar ve kuvvetli sultanlar (Allah'ın rahmeti üzerlerine olsun) zamanlarında Leh (Polonya) vilâyetinin kralları olan Kral Kazimir ve Kral Sigmut ve Kral Avgust ve sair krallar zamanında her biri ile dostça bir barış ve yarış içindeydi. Öyle ki iki yurt arasında bir öksüz çocuk ve dul kadın; fakir ve dilenciler başlarına altın tac takıp yürüseler bir zarar görmezlerdi. Müslüman tacir ve bezirganlar gidip gelirken zarar ve ziyan görmezler, emin gidip aman gelirlerdi. Ama Kral Avgust' un vefatından sonra Leh memleketinde kral olacak oğul kalmadı. Leh memleketi on iki yıl kralsız kaldığından, memleketteki hırsız ve haramileri, Leh voyvodaları, beyleri ve kermen komutanları tarafından durdurulup zapt edilemedi. Onlar, bu hırsız ve harami Kazaklara yiyecek ve gemi verip, Özü (Dnepr-Dnipro) nehrine yolluyorlar, bunlar tatar hayvancıları alıp hayvan ve at yılkısın sürüyorlardı. Sonra Macar kralları soyundan kral İştefan ${ }^{10}$ Leh memleketine hükümdar olduktan sonra çoğunluğu Özü nehri civarında Hristiyan hırsız ve harami kazakların saygısını kazanmak ve onları kendi tarafına çekmek için bunları Özü suyundan indirdi. Bu yüzden devletli ve saadetli Padişah Hünkâr Hazretlerinin Özü suyu civarındaki Cankermen ve Akkermen ve Benderkermenlerinin arasında ikamet eden küçük ve büyükbaş hayvan

\footnotetext{
${ }^{4}$ O dönemdeki Rusya - büyük kısmı Leh yöneticiliği altında bulunan Kiyevskaya Rus' (Kiev Rusya'sı) denilen şimdiki Ukrayna topraklarıdır. Bugünkü Rusya ise Moskova veya Moskoviya denilirdi.

${ }^{5}$ Soylu beyler

${ }^{6}$ Orta sınıf şehirliler.

${ }^{7}$ Seym; Polonya parlamentosu

${ }^{8}$ Kirım

${ }^{9}$ I Sigmund (Sigizmund) Avgust (hayat yılları 1520 - 1572; D. Y. Knışın). Litvanya Ulu knezi (1544-1572), Polonya kralı (1548-1572).

${ }^{10}$ Stefan Batoriy (hayat yılları 1533-1586) - Polonya komutan ve kralı (1576-1586).
} 
yetiştirenler ile gariban tüccarlar zarar ve ziyan görmüşlerdir. Böylece Rahmetli Babamız Devlet Giray Han'ın, ağabeylerimiz hanların, kendimizin, sultanların ve Beşbaş Tatar Kazakların her kış çapul/yağma yapıp iki yurdun birbirine düşman olmasına işte bu Özü Suyu civarındaki harami ve hırsız Hristiyan Kazakları sebep olmuştur. Halen Leh memleketi kralı olan Asoşka ${ }^{11}$ kral oğlu karındaşımız kral Zigmut $^{12}$ devlet eşiğimize büyükelçisi Bronevskini ${ }^{13}$ bölek hazinesi ile gönderip önceki barış, yarış, dostluk ve muhabbet âdetince iki yurdumuz arasında tüccarlar hedeflerine korkusuzca varsınlar ve emin gidip aman gelsinler dediler.

Böylece, gönderilen Bölek hazinesi hoş görülüp kabul edildi. Kardeşimiz Zigmut ile dostluk, muhabbet, barış ve yarışımız şu şartlar üzerine kuruldu; Özü suyu civarındaki harami ve hırsız Hristiyan kazakları hepsini sürülecek, Özü suyundan çıkarılıp bir yere toplanarak zapt edilecek. Ve dahi gönderdiği bölek hazinesi her yıl gönderilecek ayrıca defterimize kayıtlı kişilerimizin/kullarımızın bağışları bölek hazinesi ile birlikte gönderilecek. Ve dahi Kalgay sultanı olan kardeşimiz Fetih Giray sultana dahi altmış pastav ${ }^{14}$ çekmen bölek hazinesi ile göndersinler. Ve on iki kişiye dahi bağış göndersinler.

Eğer bu şekilde bölek hazinesini vererek bağışlar ile gönderirlerse ve Özü suyu içinden Hristiyan kazakların birini bile bırakmadan tümünü çıkarırlarsa, barış ve yarış, dostluk ve muhabbet içinde olurlarsa ben kendim Gazı Giray Han veya Ulu Küçük Kalgay Sultan, başlıca bütün sultanlar, begler ve mirzalar Tatar çerimiz ile yağmaya, talana ve zarar ziyan göstermeye gitmeyecekler. Eğer sen kardeşimiz Zigmut bu anlaşma ve şartlara uyarsanız, vallahi ve billâhi ve tallahi dostunuza dost ve düşmanınıza düşman oluruz. Ve dahi Beşbaş Kazaklar gidip vilayete bağlı olan köylerinize akın yaparak esir getirecek olurlarsa ben, kardeşiniz Gazi Giray Han getirilen esirleri geri alıp göndeririz. Ve Beşbaş Kazakların dahi haklarından geliriz. Özü suyu civarındaki Hristiyan Kazakları çıkarmazsanız ve bunlar Tatar hayvancı ve çobanları zarar ziyana uğratırlar ise, siz kardeşimiz Zigmut bilmiş olun $\mathrm{ki}$, dostluk ve muhabbet, barış ve yarış olmaz. İki yurt emin ve aman olmazlar. Ve dahi Siz Zigmut kardeşimiz Özü Suyu içinden Hristiyan kazaklarınızı çıkarır olsanız ise Özü suyu boyunda yaşayan kara halkınızdan vatandaşlarınız bizden emin olarak paralarıyla gelip Çorak (?) tuzumuzdan tuz satın alıp gitsin. Sen Zigmut kardeşimizin memleketine ve bizim memleketimize tüccarlar korku bilmeden ve usanmadan emin gidip aman gelsinler.

Halen büyükelçiniz olan Bronevskiy'nin gözü önünde bu ant, şart ve akit ederek bu ahitname Yarlığ-1 Şerif-i Hakani olarak hazırlanıp altın nişanlı mührümüz basılıp kendi İç ${ }^{15}$ beyi ve vezirimiz olan Kasım'ı büyükelçimiz olarak bu ant ve şart ve ahdimizi Siz Zigmut kardeşimize bildirmesi için gönderdik. Ve dahi siz Zigmut kardeşimiz Moskova düşmanınıza atlandığınızda, ben Gazi Giray Han kardeşinizden yardım için Tatar çerisini dilerseniz harçlık flori gönderirseniz, biz de bu florini çerimize verip düşmanınız üstüne yollayacağız. Ve dahi biz Gazi Giray han kardeşinizden giden büyükelçimizi iki aydan fazla tutmadan bölek hazinesi ve bağışlar ile çabukça biz kardeşinize gönderiniz. Ve Siz Zigmut kral kardeşimizden bize gelen büyükelçinizi dahi iki aydan fazla tutmadan, sen Zigmut kral kardeşimize çabukça göndeririz.

\footnotetext{
11 (III Yuhan önceden prens sonra İsveç kralı: 1568-1592 idi)

12 (III Sigizmund, Polonya kralı: 1587-1632)

13 Polonyalı asilzade olan Martin Bronevskiy kendi kralın büyükelçisi sıfatında Kırımı ziyaret ederek görevi bitirdikten sonra "Kırımın tasviri" (Tartariae Descriptio) adlı seyahatname tarzında yazılan meşhur bir eser yayımladı (bkz. Bronevskiy.1970).

${ }^{14}$ (çuha, ceket)

${ }^{15}$ Saraya yakın asilzade, saray hadimi.
} 
Şimdi sen kral Zigmut kardeşimiz bilmiş olun ki, Özü suyu içinden kazaklarınızı çıkarmaz ve yığıp zapt etmez olursanız ve onlar da biz kardeşinizin hayvancı ve çobanlarına zarar eder ve Padişah Hünkâr Hazretlerin kermenleri ve reayasına zarar ve ziyan ederlerse dostluk ve muhabbetlik ve yarış ve barış olmaz. İki yurdun reayası ve kişileri zahmet görür Devletli Padişah Hünkâr Hazretleri de rezil eder. Bu akit ve şart ve ant üzerine durulmak gerekiyor diye, ahitname yarlıği Şerif-i Hakan-i yazıldı.

Cümadi-ül- evvel ayında. Sene bin.

Bi makam-i Almasaray Dar'ul-Hakan-i. Han Gazi Giray bin Han Devlet Giray.

Altın Ordu Türki'si resmî yazılı dil olduğu XIII-XVII. yüzyıllarda Osmanlı edebi dil gelenekleri de Kırım'da kök salmaya başlayarak XVI. yüzyılın ortalarından itibaren oldukça aktif kullanılmaya başladı. Bağımsız Kırım Hanlığın 2. hanı I. Mengli Giray Han ${ }^{16}, 1475$ senesinde imzaladığı Osmanlı İmparatorluğu'na bağlanacağını bildirdiği ahitname ile bu dil süreçlerini hızlandırmıştır (İnalcık. 1944. S. 192-93).

Altın Ordu Türki'si Kırım Hanları, Tatar aristokrasisi ve münevverleri arasında Cengiz Han ve onun evlatlarının hüküm sürdüğü parlak ve şanlı tarihin dili olarak kültürel önem taşıyordu ve prestijliydi, aynı zamanda Tatarlarının ana dili sayılıyordu. Ayrıca Kırım Hanları için bu dilde konuşmak, mektup ve yarlık yazmak bir taraftan kendi bağımsızlıklarının, diğer taraftan da önceki ulu ve şanlı atalarıyla alakalarının bir göstergesiydi.

Kırım'da Zincirli Medrese banisi, genellikle bilim ve edebiyat inkişafının destekçisi olan hatırlattığımız I. Mengli Giray Han sadece yarlık ve mektuplarını (Osmanlı sultanlarına yazılan hariç) değil telif ettiği şiirleri Altın Ordu lehçesi ile yazıyordu. Maalesef onun ancak bir eseri zamanımıza ulaşabilmiştir. Bu eser de Halim Giray tarafından XIX. yüzyılda "Gülbün-i Hânân" adlı "tevârih" tarzında yazılmış Kırım Tatar Hanları Tarihi kitabı sayesinde bilinmektedir (Halim Giray. 2013).

Şiir, zamanının geleneksel tasavvuf anlayışı çerçevesinde yazılmıştır. Gazelde insanın değeri ve bu değeri oluşturan İlahi işlenmiştir. Özün karşısında ise insanı bu yaratıcı özden, hakikatten ve gerçek dünya olarak görülen ahiretten yaşamından uzaklaştıran fani dünya yaşamı, şan şöhret arzusu ve maddi zenginlikler yer almaktadır. Bu fani dünya, hakiki dünyanın ancak bir yansıması ya da gölgesi olarak değerlendirilir. İnsanın gerçek amacı, kendi içindeki Allah'ın kudretinin kıvılcımını hissederek, tüm varlığın anlamını kavramaktır. Böyle bir hisse bağlı hayaller, şiirde: “Senüng murg-ı hayâlüni içinde asramaq içün"17 misraryla ifade edilmektedir. İlahi özün akılla idrak edilemez olduğu gerçeği sebebiyle oluşan imgeler ve melankolik duygular, Türk şiirine İran ve Arap edebiyatlarından geçmiştir.

\footnotetext{
${ }^{16}$ Hükümdarlık yılları: 1467, 1469-1475 ve 1478-1515.

17 "Senin hayalinin kuşunu içimde beslemek için..."
} 
Orta Asya'daki ilk Müslüman mistik şairlerden biri olan şimdi Türkistan adıyla bilinen Yeside yaşamış Ahmet Yesevi' dir (1093-1166). Onun tarafından tesis edilen şiir ekolü hem de Yeseviye denilen Sufi akımı Türk dünyasında geniş yer buldu. Kendi şiirlerinde kullandığı, aslen Fars ve Arap kökenli, imge, mecaz, kinaye ve istişareler zamanla Anadolu, Kırım ve Kafkasya şairleri tarafından taklit edildi. Belki de ilk kez Ahmet Yesevi'nin "Hikmet"lerinde kullanılan 'dîde-i bînâa' ifadesi 1. Mengli Giray'ın söz konusu şiirinde de görülmektedir. Bu ifade 'görücü' veya 'gözü var olan yapı/nesne' olarak çevrilebilir. Aynı zamanda mecazen 'nesnelerdeki gizli özü gören' anlamı verilebilir. ${ }^{18}$ Bu kullanım, Arap ve Fars dünyasıyla sıkı temas halinde olan Müslüman Türklerin yaşadıkları geniş coğrafyadaki edebi geleneklerin ortaklığını göstermek için örnek gösterilebilir. "Dîde-i bînâa" “ifadesi Ahmet Yesevi'nin Hikmet'lerinin yanında Osmanlı şairlerinden Nesimi ve Usûlı̂’ de de görülmektedir.

\author{
Gazel \\ Firâkındıng menim hâlüm sorar bolsang eger cânâ \\ Köngülde nâr közde âb u dilde âh olur peydâ \\ Senüng murg-1 hayâlüni içinde asramak içün \\ Bolupdur kirpigüm birle kafes bu dîde-i bînâ \\ Menüm ol Hân-ı Mengli kim muhannet mülki şâhımun \\ Cihânung mülk ü mâlına gurûrum yok durur aslâ. (Gültekin 1998: 58)
}

Yukarıdaki I. Mengli Giray şiiri, aslen Altın Ordu Türki'si ile yazılmış olsa da Oğuz ağzının etkisi duyulmaktadır. Bilindiği gibi şiirin yazıldığı dönemde, Osmanlıca Kırım’da geniş çapta yayılmamıştı. O yüzden bu etki muhtemelen yerel Oğuz lehçesinden kaynaklanmaktadır. Mengli Giray'dan yüz sene sonra hanların yarlıkları ve folklorik eserler dışında Kırım'da divanlar, tasavvufi risaleler, tarihler ve diğer edebiyat eserleri çoğunlukla Osmanlıca yazılırdı. Kırım Hanlığı'nın yıkılmasından sonra bu edebiyat hakkında bazı bilgileri Bursalı Mehmet Tahir ve hanlar soyundan asıllı Halim Giray hem de daha sonraki araştırmacılar verdiler (Bursalı.1990. Halim Giray. 2013). Ama yine de eski Altın Ordu Türki'si ve Oğuz Kıpçak yerel Kırım lehçesi o dönemdeki edebiyattan tamamen silinmedi.

İsmail Hikmet Ertaylan, örnek için getirdiğimiz yarlığın yazarı Bora Gazi Giray’ın şiirlerinin tahlilini yaparken, üç edebi lehçede yazıldığını belirtmektedir. Böylelikle çağdaş Kırım Tatar lehçesi üç edebi geleneklerin kaynaklarına dayanıyor: Oğuz-Kıpçak karakterli olan Kumanca, Karluk-Uygur dalına ait Kırım Türki'si ve Osmanlıca.

Bu lehçelerden biri, Orta Asyalı, Herat şiir okulun kurucusu, Çağataycayı klasik bir yazı dilin haline getiren Ali Şir Nevai'nin etkisi altında yazılan şiirlerinde kullanılan Çağatay Türkçesidir. Fakat Ertaylan, Gazi Giray’ın 'Neva'î tarzı şiirim’ dediği şiirlerinin dili için '(...)

\footnotetext{
${ }^{18}$ Sufi mistik şairlerin sembolik dili hakkında, Ye. E. Bertel's “Tasavvuf ve Tasavvuf Edebiyatı" adlı eserinde detaylı malumat vermektedir (Bertels. 1963).
} 
Neva'î zamanının Çağatay lehçesi değil, belki Azerî, Osmanlı tesirleri altında kalan muahhar Çağatay lehçesidir.', yorumunu yapmaktadır (Ertaylan. 1958. S. 32).

Bugünkü Türk dilinin tarihi sınıflandırılmasına göre çağdaş Özbek ve Yeni Uygur dillerinin temeli olan Çağatay lehçesi, XV-XVI. yy.larda Orta Asya'da ortaya çıkmıştır. Altın Ordu Türki'si gibi Çağatayca da yazılı edebi dil sıfatıyla Karluk-Uygur lehçelerine dayanarak kurulmuştur (Blagova. 1997. S. 148). Bu iki lehçenin içyapısı başta olmak üzere ortak unsurlarının çokluğundan dolayı Gazi Giray Han'ın 'Neva'î tarzında' şiirlerini, yarlıkta görülen Altın Ordu Türkisinin bir varyantı sayabiliriz. Şiirlerin dilini, yarlığın dilinden ayırt edici elemanlar, ilk önce Farsça ve Arapçadan alıntı kelimelerin büyük miktarı ve çeşitliğiyle ilgilidir. Tabi ki, Altın Ordu Türki'sinden farklı olarak Kırım Türki’sinde Kuman (Oğuz - Batı Kıpçak) etkisi duyulmaktaydı. Bora Gazi Girayın 'Neva'î tarzındaki' şiirlerinde o eski Türk lehçesinin etkileri görünmüyor ama İsmail Hikmet Ertaylan'ın kayıt ettiği gibi Oğuz unsurlarının sayısı gayet çoktur.

Osmanlıcayla olan ilgi, Kırım'da 1920'lerin sonuna kadar sürmekteydi. Asırlarca derine inen kültürel bağlantılar, Kırım Tatar münevver, siyasetçi ve bilim adamlarının karşılaştıkları baskı ve kıyımlarla Bolşevikler tarafından suni şekilde kesilmiştir. Osmanlıcayla yazılan Kırım edebiyatı komünistlerce yasaklanıp, Kırım’da konuşulan Selçuk ve başka Oğuzların lehçelerinin temelinde inkişaf ettirilen ağızlar yabancı ve Türk burjuvalarının konuştuğu ve yayınladığı dil olarak ilan edildi. Ama bugün biliyoruz ki, XIVXIX. asırlarda Türk aleminde aynı kültür, aynı alfabe ve aynı veya benzeri motif ve süjeleri kullanılan her yerde anlaşılan geniş bir ortak edebiyat vardı. Bu edebiyat birliğine delil teşkil eden nazire, tanzir veya sadece taklit olarak yazılan numunelerin sayısı çoktur. Edebi dilin iletkeni olarak bahis ettiğimiz Bora Gazi Giray'ın şair Nesimi'yi büyük ustalıkla taklit ederek kendi kızı Hanzade'ye ithaf şeklinde Osmanlıca şiiri güzel bir örnek olabilir:

Habibim munisim yârim derde dermanım

Enîsim yâr 1 dilhâhım latifim mahremim canım

Gülendamım dilârâmım vefâdârım havâdârım

Özi şahım yüzi mâhım boyı serv i gülistanım

Peripeyker lebi şekker sözi gevher özi huşter

Kaşı yâ kirpiki hançer sühanver la'li mercanım

Yüzi gül saçı reyhânım lebi mül çeşmi hunharım

Ki sensen hasılım varım muhassal dinim imânım

Könül inler közim ağlar yaşım çağlar firakında

Terahhum eyle ey şâhım tekellüm eyle ey hanım

Çıkıb seyre suvar olmuş yolunda ten gubâr olmuş

Niçeler hâksâr olmış kezer nazile cananım

Közim yaşın döker her dem çeker zahmine yok merhem

GAZAYİ kanı bir mahrem diyem hâl i perişanım. 


\section{SONUÇ}

Sonuç olarak, tüm Türk milletlerinin dilini, edebiyatını ve tarihini yansıtan yazma ya da belgeler okunmamış, okunanların büyük bir kısmı ise yeterince incelenmemiştir; özellikle başta metinler olmak üzere, diğer kültürel değerlerin de mahvolduğu Kırım Türkleri için. Bu tür çalışmalarla Kırım Türklerinin tarihleri; edebiyat ve dil geçmişleri ile edebi gelenekleri aydınlatılabilir, bazı müphem noktalar açıklığa kavuşturulabilir ve altlarında yatan nedenler ortaya çıkarılabilir.

\section{KAYNAKÇA}

Argunşah, Mustafa-Güner, Galip (2015). Codex Cumanicus. İstanbul: Kesit.

Bartold V. V. (2002). Rabotı po istorii i filologii türkskih i mongolskih narodov. (Türk ve Moğol Halkların Tarih ve Filolojisi Üzerine Araştırmalar). Moskova: 'Vostoçnaya Literatura'.

Bertels Ye. E. (1963). Sufizm i sufiyskaya literatura (Tasavvuf ve tasavvuf edebiyatı). Moskova: «Nauka»,- $524 \mathrm{~s}$.

Blagova G. F (1997). Çagatayskiy yazık (Çağatay dili) içinde “Türkskiye yaziki” (red. Tenişev). Bişkek: 'Kırgızstan',-- s. 148-159.

Borovkov A. K. (1963). Leksika sredneaziatskogo tefsira XII - XIII vv. (XII - XIII yy. Orta Asya Tefsirinin Dili). Moskova: İzdatel'stvo Vostoçnoy Literaturı. 368 s.

Brockelmann, C. (1916). “Ali's Qişşa-i Jüsuf der alteste Vorlâufer der Osmanischen Literatür"/ Berlin: Abhandlange der Bayerischen Akademia der Wissenschaften. - s.5-8. Bronevskiy, Martin (1970). “Kırım”. Çeviren: Kemal Ortaylı. Ankara: EGE Matbaası.

Bursalı, Mehmet Tahir (1990). Osmanlılar Zamanında Yetişen Kırım Müellifleri. Ankara: Kültür Bakanlığı. $64 \mathrm{~s}$.

Codex Cumanicus (1942). / Komanisches wörterbuch. Ed. K. Grönbech. - Kopenhagen: Einar Munksgaard. $289 \mathrm{~s}$.

Ertaylan, İsmail Hikmet (1960). "Yusuf ile Züleyha". İstanbul:.Edebiyat Fakültesi Basımevi. $124 \mathrm{~s}$.

Ertaylan, H. İ. (1958). Gazi Giray Han. Hayatı ve Eserleri. İstanbul: Ahmed Said Basımevi.- 92 s. Halim Giray (2013). Gülbün-ü Hânân (Kırım Hanları Tarihi). Yayına Haz. Alper Başer-Alper

Günaydın. İstanbul, Avrasya Enstitüsü Yayınları.

Gaciyeva N. Z., Serebryakov B. A. (1986). Sravnitel'no-istoriçeskaya grammatika türkskih yazıkov (Türk Dillerin Karşılaştırılmalı Tarihi Grameri). Sentaks. Moskova: “Nauka”.- 284 s.

Grigoryev A. P. (1977). “Ofitsial'nıy yazık Zolotoy Ordı XIII-XIV vv.” (“XIII-XIV yy. Altın Ordu'nun resmi dili”) içinde Türkologiçeskiy sbornik. (1981). / (Redaktör A. N. Kononov). Moskova. - S. 81-89. 
Gültekin, İbrahim (1998). Halim Giray ve Gülbün-i Hânân. Yüksek Lisans Tezi. Türkistan: Ahmet Yesevi Üniversitesi.

İnalcık, Halil (1944). "Yeni Vesikalara göre Kırım Hanlığı'nın Osmanlı Tabiliğine Girmesi ve Ahidname Meselesi," Belleten 8, S. 192-93.

Kaşgari, Mahmud. Divanü Lûgat-it-Türk. (1992). Çeviren: Besim Atalay. Dört cilt. Ankara: Türk Tarih Kurumu Basımevi.

Kırım kadıları sicillerin foto kopyaları. Simferopol, İsmail Gaspirali adına Milli Kütüphanesi. Arşiv fondu: 67 A90.

Nacip, E. N. (1975). “Türkoyazıçnı pamyatnik XIV v. 'Gülistan' Seyf Sarai i yego yazık” (XIV yüzyıl Seyf Sarai'nin Türk dilindeki 'Gülistan' yadigârı ve onun dili). İki kısmında. Alma-Ata: Nauka, Kısmı 1: 210 s. Kismı 2: 300 s.

Nacip E. D., Blagova G. F. (1997). “Türki yazık” (Türki dili) içinde "Yazıki mira” / "Türkskiye yazıki”. (Red. Tenişev E. R.). Bişkek: 'Kırgızstan'. - S. 126-138

Rustemov O. D. Stepanov Ye. N. (2016). “Gegrafiçiskiye nazvaniya v krımskih kadiaskerskih tetradyah: $k$ voprosu o proishojdenii oronima Çongar". (Kırım kazasker defterlerinde Coğrafik İsimler: Oronym Çongar soruna dair) içinde Naukovo-teoretiçnıy çasopis s movoznavstva No. 26. ONU im. Meçnikova. Odesa. S. 138-144.

Samoyloviç A. N. (1916). “Opyt kratkoy krımskotatatrskoy grammatiki” (Kırım Tatar Dilin Kısa Gramer Denemesi). А. Н. Самойлович. Petrograd: İ. Boraganskiy Basımevi. - 104 s.

Toparlı, R., Vural, H., Karaatlı, R. (2007). “Kıpçak Türkçesi Sözlüğ̈̈̈. Ankara: TDK Yayınları. $338 \mathrm{~s}$

Velyaminov-Zernov V. (1864) "Materialı dlya istorii Krımskogo Hanstva, izvleçonnıye po rasporyajeniyu imperatorskoy Akademii Nauk iz Moskovskogo Glavnogo Arhiva Ministerstva İnostrannı Del". (İmparatorluk Bilimler Akademiyse emriyle Moskova Diş İşleri Bakanlığının Baş Arşivinden çıkarılan Kırım Hanlığı Tarihine ait malzemeler) - StPetersburg: - 941 s.

Vernadskiy G. V. (1997). “Mongolı i Rus'”' (Moğollar ve Eski Rusya) / Г. В. Вернадский. Tver': Lean; Moskova: Agraf, $-811 \mathrm{~s}$.

Zaytsev İ. (2009). Krımskaya istoriografiçeskaya traditsiya XV-XIX vv.: puti razvitiya: tekstı $i$ istoçniki (XV-XIX yy. Kırımın historiyografi geleneği: gelişim yolları: metinler ve kaynaklar). И. В. Зайцев - Moskova: Vostoçnaya Literatura. 304 s. 